\title{
CASSIODORO E AS INSTITUTIONES DIVINARUM LITTERARUM COMO FONTE HISTÓRICA PARA A DISCUSSÃO SOBRE PRÁTICAS BIBLIOGRÁFICAS E ORGANIZAÇÃO DO CONHECIMENTO
}

\section{CASSIODORO Y LAS INSTITUTIONES DIVINARUM LITTERARUM COMO FUENTE HISTÓRICA PARA LA DUSCUSSION SOBRE LAS PRACTICAS BIBLIOGRAFICAS E LA ORGANIZACIÓN DEL CONOCIMIENTO}

\author{
Giulia Crippa - giuliac@ffclrp.usp.br \\ Doutora em História Social pela Universidade de São Paulo \\ (USP). Professora do Programa de Pós-Graduação em \\ Ciência da Informação da USP.
}

\begin{abstract}
RESUMO
Introdução: A Ciência da Informação discute o acesso e uso da Informação. No âmbito de tais discussões, consideramos que a Bibliografia representa um dos alicerces, em quanto metadisciplina, para o tratamento dos documentos. Se observada pela perspectiva do "gesto bibliográfico", percebe-se que sua história é bem anterior à invenção da impressão dos livros, podendo ser individualizada em seus elementos principais em um tratado do VI século, o $D e$ Institutione Divinaruam Litterarum de Cassiodoro (c. 490-c. 584).

Objetivos: Reconstituir historicamente a recorrência de problemas informacionais enfrentando-os de um ponto de vista intelectual, através de uma fonte histórica, o De Institutione Divinarum Litterarum, de natureza Bibliográfica, através da trajetória de uma reorganização dos saberes e dos registros pagãos e cristãos em um percurso dos conhecimentos considerados não somente legítimos, bem como estruturais para a sociedade. Para tanto, observam-se alguns aspectos da obra de Cassiodoro, enquanto dispositivo de seleção, organização e mediação informacional.

Metodologia: Revisão da literatura e leitura das fontes.

Resultados: Primeira tentativa de sistematização da literatura patrística (à qual o próprio Cassiodoro deu uma contribuição notável, com a composição de um imponente Comentário aos Salmos), os nove capítulos do De Institutione Divinarum Litterarum são um livro feito por livros, entre os autores canônicos da literatura religiosa, um elenco das obras consideradas essenciais na escalada para o conhecimento divino, tendo sua presença justificada pela
\end{abstract}


criação de um programa de educação cristã e sua materialidade descrita. $\mathrm{O}$ texto é completado por comentários dedicados à escrita e à tradução delineados com poucos e claros tratos.

Conclusões: O De Institutione Divinarum Litterarum é um texto que revela as múltiplas facetas de um dispositivo da cultura manuscrita, preocupada com sua presença física na biblioteca e com a dimensão filosófica do conhecimento, explicitando os aspectos descritivos e semânticos dos documentos e dos saberes, contribuindo, nos termos de uma história que se torna antropologia na medida em que estuda o gesto bibliográfico, para as dimensões conceituais das disciplinas bibliográficas contemporâneas.

Palavras-chave: Bibliografia - história e teoria. Bibliógrafos - história. De Institutione Divinarum Litterarum - Séc. VI. Cassiodoro. Gesto bibliográfico.

\section{INTRODUÇÃO}

Nos últimos anos observa-se a presença, na literatura, de uma discussão bastante ampla sobre o acesso e uso da informação, facilitando sua recuperação estruturada em todas as tipologias de biblioteca: especializada, pública, universitária etc... A presença das tecnologias móveis impõe, ainda, uma discussão sobre a oferta de fontes qualificadas de informação. Entre os elementos da problematização contemporânea da Ciência da Informação, convém destacar, aqui:

1) A ênfase sobre o acesso, mais do que sobre a guarda dos conteúdos informacionais, que se torna possível em função das novas tecnologias.

2) A preocupação com o acesso a fontes qualificadas de informação, especialmente no âmbito da informação científico/tecnológica.

3) A construção de novos dispositivos tecnológicos e, como consequência, de instrumentos de acesso e uso da Informação.

Acreditando que, por trás das mudanças tecnológicas, existe uma recorrência dos problemas, que são enfrentados, em primeiro lugar, de um ponto de vista intelectual, nos voltamos às fontes históricas do que chamamos de "produção bibliográfica". 
Deparamos, assim, com um texto que trata de bibliografia como "cartografia" dos saberes através de seus registros, o Institutiones Divinarum Litterarum (IDL), tratado do VI século d.C. de autoria de Cassiodoro. Estamos, portanto, em um tempo longínquo, quando o livro manuscrito era a "tecnologia" disponível para o acesso aos conhecimentos registrados.

Cassiodoro, erudito estudioso da cristandade alto medieval, é conhecido por ser fundador da biblioteca de Vivarium, no VI século d.C. No entanto, é o autor desse texto, bastante relevante para o estudo antes que da bibliografia e de suas práticas - de procedimentos que podemos definir "gestos bibliográficos". Nos voltamos para a leitura do $I D L$ por oferecer, dentro de uma já clara definição dos conhecimentos medievais, um iter studiorum para os monges, articulando-se como manual de instrução, mapa de autores e de seu uso e lugar na hierarquia dos saberes.

Flávio Magno Aurélio Cassiodoro, romano de origem síria, nasceu na Calábria por volta de 485. A família, aristocrata, já tinha uma tradição, desde os tempos de Átila, em estabelecer relações políticas os invasores e, desde a adolescência, Cassiodoro ladeia o pai, como conselheiro, a serviço dos Ostrogodos em Ravenna. Já em 514 o encontramos no ofício de cônsul e, em 533, se torna prefeito pretoriano com e morreu por volta de 580 (O'DONNELL, 1979). Em um primeiro momento, portanto, foi conselheiro do rei Teodorico mas, em seguida à reconquista bizantina da Itália, foi forçado a mudar para Constantinopla, onde residiu por vários anos. Por volta de 554 voltou para suas terras, em Vivarium, onde edificou um mosteiro dedicado a Santo Martinho, cuja finalidade era de ser uma escola cristã construída em volta do estudo das Escrituras, ainda que com o auxílio de textos de autores pagãos (COURCELLE, 1948).

Para estruturar a escola, Cassiodoro constituiu uma biblioteca de comentadores da Bíblia, bem como de alguns autores clássicos, tornando-a rica em escolhas e variedade. Através das atividades 
cotidianas de manutenção, copia, restauração e transcrição dos manuscritos, Vivarium sempre foi considerado como um lugar significativo na produção dos livros no século VI.

O tratado $I D L$, em sua divisão disciplinar e em sua proposta de uma ordem (re)produzida na biblioteca, se torna exemplo de verdadeira "política da Informação", visando oferecer uma educação cristã completa, através de um texto detalhista e cheio de títulos. Não se trata, porém, de uma simples lista de livros presentes na biblioteca fundada por seu autor: a proposta de Cassiodoro é, com efeito, uma seleção de títulos para os monges seguirem um percurso de conhecimento instigante, que combina sugestões, recomendações e aponta para a disponibilidade ou a necessidade de procurar os materiais.

É ao universo do manuscrito cristão medieval que a leitura do IDL nos leva: manual para uso da biblioteca, catalogo e, usando um termo aparentemente anacrônico, bibliografia raisonnée em que reconhecemos e assumimos o encontro com o "gesto bibliográfico" como algo anterior à sua (re)invenção da Modernidade.

Queremos, nesse artigo, reconstruir historicamente o "gesto bibliográfico" realizado por Cassiodoro, em um momento em que, do colapso das estruturas da Antiguidade Tardia, se observa a trajetória de uma reorganização dos saberes e dos registros pagãos e cristãos na busca de um percurso dos conhecimentos considerados não somente legítimos, bem como estruturais para a sociedade.

Organizar a informação continua sendo, na contemporaneidade, uma das grandes questões. A organização da informação não é dada a priori, mas é o resultado de formações históricas voltadas para a manutenção de instituições que, por longo tempo, conservaram e disseminaram, de forma estruturada, os instrumentos e materiais de conhecimento socialmente compartilhados.

É, assim, necessária uma reflexão em relação à figura e ao papel dos responsáveis pela representação dos documentos e produtos culturais de cada época, na tentativa de compreender e reconstituir a 
maneira pela qual o espaço da informação se configura no presente. Ao mesmo tempo, essa perspectiva histórica permite reconstituir o percurso das tarefas e responsabilidades de quem atua nesse campo, em relação à manutenção e à renovação das estruturas institucionais da sociedade e da cultura. É, de fato, através de escolhas classificatórias e de representação que se torna possível a manutenção dos conhecimentos.

\section{O DE INSTITUTIONE DIVINARUM LITTERARUM NO CONTEXTO DA EDUCAÇÃO NA ALTA IDADE MEDIA}

O IDL de Cassiodoro, erudito fundador da comunidade monástica e da biblioteca de Vivarium, no sul da Itália, se apresenta como catálogo bibliográfico enquanto dispositivo de organização e recuperação daquela informação que articula as fronteiras dos conhecimentos com seus materiais, dotando-os, potencialmente, de um locus espacial na arquitetura filosófica/física de uma biblioteca.

O termo dispositivo indica, aqui,

[...] um conjunto heterogêneo, lingüístico e nãolinguístico, que inclui virtualmente qualquer coisa no mesmo titulo: discursos, instituições, edifícios, leis, medidas de policia, proposições filosóficas etc. $O$ dispositivo em si mesmo é a rede que se estabelece entre esses elementos" (AGAMBEN, 2014, p. 25)

Consideramos, portanto, o dispositivo da instituição de uma biblioteca em Vivarium, de suas práticas de condução (através da textualidade ligada à sua gestão, administração e logística), e da seleção e organização, mediante uma proposta de catálogo, dos manuscritos que refletem o acesso e o uso da informação no quadro técnico e tecnológico da época. Por esse viés, há um cruzamento evidente, no IDL entre a constituição do lócus do catálogo, com discursos, instituições, proposições filosóficas etc. daquela época.

No IDL a missão da biblioteca idealizada por Cassiodoro é de fornecer uma educação cristã coerente e marcada por uma bibliografia 
que busca traçar um percurso inovador em uma realidade política, social e cultural caótica como é nos tempos da Alta Idade Media Ocidental. A biblioteca, voltamos a destacar, não é observada, aqui, como simples fato histórico, documentário e social, mas como realização de um dispositivo estruturado de materiais aos quais confiar a responsabilidade de interpretar e representar os valores e os ideais da civilização, cristã. O IDL possui o escopo de mostrar, concretamente, as escolhas para o acervo de uma biblioteca pedagogicamente voltada à educação cristã, sinalizando as características que levam à escolha do livro e sua "localização" conceitual e/ou espacial (HALPORN, 1981).

Possui um método, que consiste na exposição de uma estrutura orgânica e da coerência de uma arquitetura disciplinar através da envergadura bibliográfica do autor. Decorre disso, como resultado, uma percurso de conhecimentos que se desenrola através de um catalogo bibliográfico planejado e construído desde as bases, em uma biblioteca que não é somente um conjunto de documentos, nem uma coleção de volumes, um texto para o qual as disciplinas históricas tem se voltado, principalmente, na tentativa de verificar a presença ou ausência dos títulos nos armaria de Vivarium: parece-nos que o IDL é a materialização dos ideais e dos instrumentos de uma organização do conhecimento voltada a interesses específicos (a civilização cristã) e a registros possíveis, como se vê pelas afirmações (o pergaminho, o papiro).

É nesse sentido que propomos uma análise do tratado de Cassiodoro: uma bibliografia, ou seja, um percurso informacional estabelecido para a obtenção de conhecimentos específicos.

Com Antiguidade Tardia se entende uma época de transição entre o mundo pagão e a Idade Média, marcada pelas mudanças em muitas esferas da vida e da cultura e, a nosso ver, um dos registros dessas mudanças pode ser encontrado no IDL. Dos dois livros que compõem o tratado - manifesto cultural e, ao mesmo tempo, diário de trabalho compilado por Cassiodoro em benefício dos próprios monges aquele destinado a uma maior difusão na Idade Média è o segundo, que 
contém um compêndio essencial das artes liberais redigido na base de fontes destinadas a se tornarem cada vez menos acessíveis.

Mas, para o leitor interessado em seguir os caminhos do "gesto bibliográfico", resulta sem dúvida mais fascinante o primeiro livro da obra, no qual Cassiodoro elabora um catálogo bibliográfico relativo não necessariamente aos livros conservados em Vivarium, mas àquelas obras que considera necessárias para uma educação cristã nos moldes dos novos tempos.

O IDL, obra clara e fácil de ser analisada e comentada, por muito tempo não foi considerada marcante para a Idade Média, pois não teve peso relevante na teologia e na espiritualidade monástica. Alem do mais, moldando-se na proposta de educação agostiniana, não aparenta, também, nenhum destaque inovador no plano filosófico. $O$ plano de estudos de Cassiodoro, redigido como uma programa especulativo, não tem sido observado nessa perspectiva, apesar dos indício de sua presença nas estruturas bibliotecárias medievais, emergindo como referencia em épocas bem mais tardias, como no caso de Hugo de São Vitor (2001), no século XI.

Com base nisso acreditamos que, se a influência espiritual de Cassiodoro é praticamente nula, em termos de implementação de um projeto cultural cristão sua obra foi um dos alicerces para a cultura do livro na Idade Média, merecendo, portanto, um papel de maior destaque no âmbito de uma história da bibliografia (JONES, 1947).

Há duas questões a serem consideradas: de um lado, na tentativa de realizar uma escola inovadora, dedicada especificamente à educação cristã, Cassiodoro institui uma biblioteca material dentro dos muros de Vivarium e, no $I D L$, encontramos inúmeras referencias à presença de títulos nos armaria do mosteiro. Por outro lado, o catálogo não pode ser considerado unicamente como espelho dos manuscritos de posse da biblioteca, mas, sim, como proposta de um percurso "pedagógico", uma bibliografia do conhecimento cristão ideal: Cassiodoro expõe suas linhas educacionais através de quais livros 
devem ser lidos para realizar o programa de educação cristã, destacando, eventualmente, quais se encontram na biblioteca e quais os desiderata.

A partir do I século a.C. se estabelece uma relação profunda entre a educação dos homens destinados à carreira pública ou à administração e um projeto intelectual fundamentado no conhecimento e prática da retórica como fundamento da política. Entre altos e baixos, desde Cícero um dos alicerces do poder imperial é representado por uma cultura fortemente fundamentada na prática desse exercício, que se alimenta através da constituição de uma memória escrita (PENNACINI apud CAVALLO; FEDELI; GIARDINA, 1998).

Entre o II e o V séc. D.C. se assiste à transição entre o mundo pagão e a cristandade, transição durante a qual as mudanças estruturais se implementam na esfera cultural constituindo e sustentando uma rede de conhecimentos destinada a caracterizar a chamada Idade Média. Para isso, vale a pena esboçar destacar, no panorama geral da situação imperial, a insurgência da Igreja que institucionaliza o cristianismo, cujo poder se define através do registro, organização e distribuição de obras escritas. Todavia, sua autoridade se constrói através de uma redefinição do espaço sagrado da escrita e do livro (FOX apud BOWMAN; WOOLF, 1998).

No II séc. d.C., o Império romano constitui não somente uma realidade poderosa e extensa territorialmente, mas também um espaço mítico em que a cidade de Roma se reveste de atrativos simbólicos, formando um núcleo imaginário sobre seus próprios esplendores destinado a persistir ao longo dos séculos: mesmo com seu desaparecimento como espaço geopolítico, Roma permanece como alegoria do poder e do Estado. Nessa época, as fronteiras romanas já alcançaram seus limites: o sul da Inglaterra, a fronteira germânica e o espaço médio-oriental cercam uma vastidão territorial que se administra pela assimilação dos núcleos populacionais. Com o termo "bárbaro" designa-se o conjunto de povos que, mesmo aculturados pelos contatos 
com o mundo romano nas áreas controladas pelo império, preservam especificidades sociais e culturais. À pressão provocada pelos bárbaros nas áreas de fronteiras, especialmente nos instáveis Bálcãs, se unem as dificuldades políticas internas.

Mesmo as populações mais distantes do coração do império são atraídas pelo mito que se espalha de uma Roma "de ouro": o Império é rico, o Império é poderoso e sua fama se espalha, despertando desejos, rebeldia e cobiça.

Ao mesmo tempo em que as populações bárbaras entram em contato com a "imagem" de Roma, os romanos também absorvem algumas das características dos povos com os quais entram em contato. As influências de origem oriental, são particularmente sugestivas: é lá que se originam os cultos místicos destinados a um grande sucesso em Roma: o culto de Mitra, da Grande Mãe Cibele fizeram muitos adeptos entre a elite.

Por outro lado, os elementos mais pobres e fracos, como os escravos e as mulheres, também aderem a cultos importados da área médio-oriental, e mais especificamente a uma versão ocidentalizado do culto judaico de Javé. Mas como podiam, esses elementos aparentemente incultos apropriar-se dos conhecimentos religiosos, a ponto de tornar o cristianismo um dos elementos de desagregação das sociedades antigas? As novas práticas implicam na possibilidade de acessar as informações sobre os preceitos.

$O$ afluxo de bárbaros entre as fronteiras romanas parece em constante aumento e, além de representar uma ameaça militar, eles estão presentes como mão de obra escrava ou como aliados e, eventualmente, com papeis e atribuições estratégicas no setor defensivo do Império. As populações não romanas, atraídas pelas mordomias dos cidadãos romanos, pressionam o centro, em busca de melhores condições de vida. Sua penetração nas estruturas do Império é interpretada a partir de um conhecimento ligado à tradição literária de tipo "etnológico", em que pouco valia o conhecimento de campo das 
populações. Autores como César ou Tácito tendem a revelar os aspectos cruéis e selvagens dessas populações de bárbaros. A preocupação do Império é seu próprio sustento, às custas dessas populações e, mesmo quando a cidadania romana engloba as províncias mais antigas, as medidas de controle tomadas são cada vez mais de tipo militar. A extensão dos direitos implicou na busca de novas terras para encontrar mão de obra escrava e outras fontes de impostos, empregando assim quantias crescentes de gastos no aparato militar. Ainda, o deslocamento do poder para os setores militares é cada vez mais evidente: o senado e a classe dirigente tradicional se esvaziam, e aos poucos o projeto de uma política fundamentada em um preparo no estudo tende a se reduzir cada vez mais.

Mas, ainda com as dificuldades e os problemas, em Roma as pessoas sabem ler cada vez mais, por necessidade de negócios e administração. É importante realçar a diferença entre ser alfabetizado, que pode envolver uma fatia relativamente ampla da população tanto livre como escrava, e ser leitor, que implica em uma busca ativa de textos escritos: o cristianismo soube transformar quem era alfabetizado em um público leitor, pelo menos até o III século, quando a situação de crise se generaliza e Roma não é mais o lugar privilegiado pelas elites, que se retiram para as províncias, consideradas mais tranquilas. A base doutrinária, os fundamentos do cristianismo se encontram em livros, aliás, no Livro de origem divina que se traduz na Bíblia.

Todavia, os cristãos, desde a antiguidade, produziram inúmeros outros livros, já que visionários, mártires e bispos, desde os tempos da Igreja Primitiva, escolheram confiar seus pensamentos a um suporte material escrito. Inclui-se, aqui, a redação dos Evangelhos, apesar de Cristo não autorizar ou incentivar a escrita de um livro de memórias sobre seus atos e pensamentos: seus ensinamentos são transmitidos oralmente. Cristo sabe escrever, pois há uma referencia - a única - em que ele traça palavras na areia, de forma que, aparentemente, ele não 
considera o registro escrito essencial para seus ensinamentos, pois a água apaga as palavras.

É na forma de endossar a palavra escrita por parte do cristianismo que podemos identificar e qualificar alguns aspectos da cultura medieval, considerando que os cristãos fizeram uso da cultura escrita em dois aspectos: conveniente e sagrado. Com conveniente identificamos a produção textual ligada ao cotidiano, às disputas e à formação e fortalecimento da Igreja, enquanto a escrita sagrada se relaciona diretamente com a esfera divina.

Assim como o povo judeu, os cristãos possuem textos que são vistos como Palavra de Deus, portanto, insubstituíveis por outros meios. A presença do divino na textualidade escrita torna a produção da cristandade algo totalmente diferente das narrativas e das epístolas da antiguidade, e a intensificação da cultura escrita parece ser proporcional à intensificação do poder.

O processo de transformação da Antiguidade para a Idade Media não foi imediato, demorando acerca de dois séculos. De um lado, havia a continuidade do sistema tradicional de educação clássica, fundamentada na gramática e na retórica. Do outro, os cristão mais letrados sentiam a urgência da constituição de um programa educacional específico. A proposta mais sólida, em termos de princípios, para uma aprendizagem cristã, foi formulada por Agostinho em seu De Doctrina Christiana, obra que define as regras para os intelectuais cristãos e o caminho para a interpretação das Escrituras (COLISH, 2001). Quando a religião cristã se tornou oficial nos territórios do Império, não houve uma interrupção nas escolas tradicionais, que formavam os quadros necessários para a manutenção dos ofícios das faixas de população mais abastadas e, conforme Riché (1999), no V século ainda não há alternativas a essas escolas, e a formação teológica para os religiosos só se realizou a partir dos séculos $\mathrm{V}$ e $\mathrm{VI}$, com a expansão dos mosteiros 
Com a crise política e institucional do falecido Império Romano, o conhecimento da textualidade escrita se retira, principalmente, no âmbito das comunidades cristãs dos mosteiros.

Todavia, quando o Cristianismo se torna a religião oficial do Império, as pessoas não param de enviar seus filhos para as escolas tradicionais de retórica pois ainda não há lugares, escolas que encaminhem para o estudo das doutrinas cristãs. A população mais culta não consegue, ainda, imaginar uma cultura escrita diferente da tradição clássica, na ausência, até Santo Agostinho, de um percurso de estudos religiosos formalizados mas, sim, uma acumulação desorganizada de textos escritos.

No VI século, permanecia somente a moldura da educação clássica, nos moldes da qual o próprio Cassiodoro estudou, se beneficiando do conhecimento da retórica para a constituição de sua obra, tanto nos textos como na realização material da biblioteca. Sabemos, pela sua obra Variae, redigida enquanto funcionário ao serviço da corte ostrogoda, que os professores de gramática, retórica e direito eram considerados no orçamento imperial, mas esses estudos beneficiavam uma parte mínima da população, aquela estritamente necessária ao andamento da corte (O'DONNELL, 1979).

O golpe final às antigas estruturas educacionais foi desferido pela guerra godo-bizantina, que se alastrou por mais de vinte anos e deixou os antigos territórios imperiais devastados. Resultado dessa crise foi exatamente a tentativa de estabelecer escolas cristãs na formulação de seus curricula, e os lugares que assumiram esse papel foram os mosteiros. Porém, esses eram lugares em que se privilegiava não tanto o estudo textual, quanto as práticas ascéticas. Não há, portanto, uma estrutura, um "plano de estudos" que define os novos percursos do conhecimento, ao mesmo tempo em que deparamos com uma rejeição, cada vez maior, da cultura clássica: o abandono do mundo é, também, o abandono da aprendizagem secular, como bem revela o exemplo mais conhecido de São Bento e de seus mosteiros, dotados de uma regra 
que estabelece uma série de obrigações em relação à leitura. É, aqui, necessária uma comparação entre o livro como fator de cultura, em São Bento e em Cassiodoro, para entendermos plenamente o peso do IDL, que se revela uma poderosa correnteza subterrânea, em relação à função atribuída aos livros e ao papel do leitor, para os séculos seguintes.

Nos mosteiros beneditinos a lectio é limitada à própria Regra, aos livros litúrgicos, à Bíblia - em particular aos Salmos - e a poucos outros textos religiosos. Havia monges analfabetos e incultos, e tudo induz a crer que nos mosteiros beneditinos do século VI havia poucos livros, unicamente de natureza religiosa e cuja característica principal era a simplicidade. A cultura gramatical e retórica tradicionais, já recusadas pelo santo fundador, eram ausentes da vivência das mais antigas comunidades beneditinas.

As IDL introduzem uma época em suas primeiras linhas: Cassiodoro, durante o pontificado de Agapito, imaginou a criação de uma "faculdade teológica" romana: uma instituição que teria a tarefa de contrastar o predomínio das humanae litterae na instrução superior:

Sabendo como cresce, com grande impulso, o estudo das letras profanas, de tal modo que grande parte dos homens crê poder, através dele, alcançar a prudência da carne, fui invadido de uma grandíssima dor ao constatar a ausência de mestres públicos para as Sagradas Escrituras enquanto pululam as celebridades dos autores profanos. Procurei então, junto com 0 beatíssimo Papa Agapito, que a cidade de Roma recebesse professores de uma escola cristã onde as almas pudessem receber a salvação eterna e a língua dos fiéis se embelezasse pela eloquência puríssima e casta, assim como outrora houve por muito tempo na cidade de Alexandria, e também recentemente na cidade de Nísibe dos sírios, por parte dos hebreus. As guerras, porém, e as turbulentas batalhas extraordinárias, que ocorreram nas regiões da Itália, fizeram com que meus desejos não pudessem se realizar, pois as coisas da paz não têm lugar em tempos agitados. A caridade divina obrigou-me, pois, por este motivo, a escrever estes livros para vocês, para que fizessem as vezes de um mestre de iniciação. 
Através deles, assim considero, a ordem das Escritas Divinas e o conhecimento breve das letras seculares revela-se como obra divina. Talvez menos claros, pois neles se encontra não uma eloquência afetada, mas uma narração necessária. Sem dúvida, é conhecida a grande vantagem de se ter coisas escritas, pois através dos livros se aprende, lá onde a saúde da alma, assim como a erudição secular se ensina que (deles) se originam. Nesses confio não a própria doutrina, mas as sentencias dos antigos, que é lícito que os descendentes louvem e que prediquem aquilo que é ilustre. [...] Por isso, amados irmãos, aproximemo-nos sem vacilar das Sagradas Escrituras pelas exposições dos santos padres, como por uma escada de visão. Que mereçamos, aproveitados pelos seus ensinamentos, chegar efetivamente à contemplação do Senhor. Esta talvez seja a escada de Jacó pela qual os anjos subiam e desciam e feliz será aquela alma a quem Deus conceder formar-se na intimidade deste caminho; mais feliz ainda será aquele que nele souber indagar pela inteligência da vida, aquele que, sabendo despojar-se dos pensamentos humanos, souber revestir-se do discurso divino (CASSIODORUS, c2007, Prefatio, 537, p. 1106-1107).

Na obra de Cassiodoro é possível destacar como pedagogia cristã e estudo da Bíblia, reflexão espiritual e preocupações filológicas (ou mesmo simplesmente gramaticais: a última obra de Cassiodoro, composta quando o autor tinha mais de noventa anos, é um pequeno manual, o De Orthographia) são as diretrizes ao longo das quais se moldam as atividades de Vivarium, um mosteiro que, de fato, antecipa a estrutura organizativa e a função cultural que as instituições monásticas assumirão de modo mais acentuado ao longo dos séculos seguintes.

No IDL Cassiodoro descreve a biblioteca ordenada, mirabilis genus operis (IDL, 538) (CASSIODORO, 1894, p. 1107), como um conjunto inventariado de textos - ou partes deles - onde são avaliadas e contidas observações e conhecimentos, fontes inerentes à totalidade do mundo cristão. Cada parte é um lugar repertoriado, onde se encontra reunida toda uma série de itens pertinentes. Essa obra, essa tópica da memória, estrutura o que se apresentaria como entendimento livre e sem rumo; o percurso em que o espírito se engaja previne que a 
inteligência natural se perca exatamente a partir da instituição desses lugares. O feitio de Cassiodoro consiste na relação entre a estrutura e seu conteúdo. É a estrutura para a educação que prima, disposta em tópica da memória, lugar da memória que organiza a retórica, a dialética, a poesia, a jurisprudência. Essa estrutura reúne em um único lugar (a memória treinada) tudo que o saber humano precisa reter sobre o mundo. Esta estrutura não é inata, nem passivamente adquirida, mas se constrói ao longo da educação. Cada texto, que a informa, será necessariamente colocado dentro da estrutura desse inventário, encontrando seu lugar certo, levando sua contribuição ao fundo geral. Sem esse "berço", sem essa estrutura, não teria nem invenção, nem inventário, nem experiência, nem, por consequência, conhecimento somente um magma inútil, informe, uma selva confusa de materiais caóticos. Essa memória, dotada de uma ordem consciente é o catálogo de uma biblioteca de textos, tornados acessíveis e úteis (CARRUTHERS, 2002).

$\mathrm{Na}$ comunidade fundada por Cassiodoro, o mosteiro era, principalmente, uma escola, na qual se ensinavam tanto as ciências sagradas como as profanas, embasadas em uma concepção totalmente livresca e filológica da cultura. No prefácio das $I D L$ encontra-se a seguinte afirmação: "Quocirca, si placet, hunc debemus lectionis ordinem custodire, [...] auctoritate divinam in codicibus emendatis jugi exercitatione meditentur, [...] ne vitia librariorum impolitis mentibus inolescant [...]" (CASSIODORUS, c2007, Praefatio, 537, p. 1107), isso é: "por isso, se isso agradar, precisamos preservar a ordem das leituras, [...] meditar, nos códices emendados, sobre a autoridade divina através do exercício, [...] para que os defeitos dos livros não aumentem por causa das inteligências grosseiras."

No texto das $I D L$, além da rica mensagem cultural percebe-se a presença de elementos novos e destoantes com a impostação geral do discurso. Por exemplo, quando Cassiodoro é forçado a justificar a ignorância dos irmãos analfabetos ou incultos, ou quando deve fornecer 
uma interpretação alegórica da escrita (como no capítulo De antiquariis et commemoratione ortographiae em que se lê: "quod factum Domini aliquo modo videntur imitari, qui legem suam (licet figuraliter sit dictum) omnipotentis digiti operatione conscripsit" (CASSIODORUS, c2007, $X X X, 555-D$, p. 1145), "Aquilo que é de Deus de outra maneira se vê publicar, coisa que é lícita. (Assim dito mais figurativamente), do dedo onipotente compus na operação".

A proposta de Cassiodoro não é voltada aos incultos, não busca qualquer leitor: volta-se, principalmente, para uma elite de poucos cultos ainda capazes de entendê-lo. Da escrita ele dá uma interpretação puramente instrumental, em função da divulgação da mensagem cristã e da cultura tradicional: em uma palavra, antiga (COURCELLE, 1948).

\section{O DE INSTITUTIONES DIVINARUM LITTERARUM COMO REALIZAÇÃO DE UM "GESTO BIBLIOGRÁFICO"}

Nossa fonte de estudo, o IDL, foi redigido com a finalidade principal, se não única, de fornecer uma bibliografia completa para os monges de Vivarium, ainda que tenha se disseminado, em seguida, em outros centros monásticos (O'DONNELL, 1979). Como já dissemos, a obra é dividida em dois livros, o primeiro dedicado às leituras sagradas, o segundo, de maior circulação durante a Idade Media, às leituras humanas.

Ao longo dos nove capítulos que constituem o primeiro livro do $I D L$, Cassiodoro oferece os alicerces para o estudo da Bíblia, através dos comentaristas e da literatura clássica, selecionando textos que permitiriam aos monges seguir o programa da educação cristã. Dos textos selecionados e listados não confirma a presença na biblioteca, mas oferece, ainda assim, detalhes sobre suas características físicas e suas marcas. Outras vezes, cita e referenda obras que servem somente como exemplo, mas cuja leitura não é necessária. A bibliografia de Cassiodoro contém a descrição cuidadosa da utilidade de alguns 
autores, tomando a precaução, em vários casos, de apontar opiniões heréticas ou, simplesmente, discriminando entre as partes que devem ser lidas e aquelas não aconselháveis. No IDL são indicados, também, aqueles autores cujos trabalhos deveriam ser transcritos e traduzidos dentro do próprio scriptorium, de Vivarium, bem como os que já tinham suas obras copiadas. Em resumo, não se pode considerar o IDL como um catálogo relativo a uma única biblioteca mas, sim, um trabalho que busca delinear o campo dos estudos cristãos através de indicações ponderadas, algumas das quais estavam presentes no local. Não sabemos, de fato, o conteúdo de Vivarium, pois Cassiodoro escolheu um percurso de leituras que combina sugestões, recomendações, referencias à posse e desiderata.

O IDL apresenta, nesse sentido, dois aspectos do gesto bibliográfico realizado por seu autor: em primeiro lugar, estabelecendo um centro de excelência para os estudos cristãos, Cassiodoro abastece a biblioteca de manuscritos. Em seguida, expõe os princípios dessa educação através dos títulos e dos conteúdos que considera essenciais, especificando, ao longo do texto, os livros que devem ser lidos para realizar o programa e, entre eles, os que estavam presentes na biblioteca. Isso, porém, não devem levar à conclusão de que se trate da lista completa dos trabalhos presentes em Vivarium, e é por isso que consideramos sua obra em termos de bibliografia enquanto gesto que não se limita a um único espaço, mas que abrange uma idéia mais ampla de "organização do conhecimento", isso é, na definição de Agambem (2014) acima citada, o gesto bibliográfico como alicerce de um dispositivo:

Para entendermos o porte do trabalho realizado por Cassiodoro em sua obra, trataremos de algumas passagens dos primeiros nove capítulos, que constituem o primeiro livro do IDL.

Nesse capítulos, como dissemos, Cassiodoro não confirma a presença de cada livro na biblioteca, mas tratando-se da parte mais importante do percurso pedagógico proposto, encontramos, com 
frequência, afirmações como "Reliquos vero códices" (CASSIODORUS, c2007, Praefatio, 538, p. 1107) IDL, , "Reliqui etiam vobis" (IDL, I, 540-B, p. 1112), "Reperi etiam" (CASSIODORUS, c2007, II, 540-D, p. 1113), onde o verbo relinquo, is, liqui, lictum, ere se traduz com "legar", "deixar", e o verbo reperio, is, reperi, repertum, ire significa "obter", "encontrar", isso é, trata-se de livros que, provavelmente estavam presentes em Vivarium. Por outro lado, encontram-se afirmações como "reperire non potui" (CASSIODORUS, c2007, II, 540-D, p.1112), ou "non reperi" (CASSIODORUS, c2007, 540-A, p. 1114) ou, ainda os desiderata, como na frase "quoniam unum codex onerosus quibusdam fratribus poterat invenire" (CASSIODORUS, c2007, IV, 541-D, p. 1115), isso é: "Quando um precioso codex poderá ser encontrado por algum irmão", apontando sua falta, frase seguida pelo desejo "Habeat ergo biblioteca vestra unum ex his codicem, ad quem recurratis", isso é: "Que a biblioteca de vocês possua esse livro ao qual (vocês possam) recorrer" (CASSIODORUS, c2007, IV, 541-D, p. 116-17).

Cassiodoro fornece descrições detalhadas, para evitar confusões, de determinados livros: sua posição, seu aspecto físico, suas marcas. Há, também, livros que Cassiodoro somente cita, mas não considera importantes para a leitura dos monges.

A longa lista de Cassiodoro apresenta outro aspecto relevante, o de nos fornecer a referência de livros que se perderam ao longo dos séculos, como o Quaestiones III de libro III Regum ad Abundantium, ou - Annotationes breves in omnes prophetas e o Commentarius in IV Evangelia; ainda, o Sermon de Abessalon, o Tractatus in Epistulam lacobi e o Homiliae in librum sapientiae de Santo Agostinho e, entre os clássicos, o De forma mundi de Sêneca.

Um certo interesse é dispensado para autores como Orígenes traduzido por São Jerô, que, nas palavras de Cassiodoro, deve ser lido com cuidado, evitando algumas partes que contradizem os autores canônicos: 
Item in Octateucho eloquentissimae nimis homiliae sunt Origenis in codicibus tribus, quem multorum quidem Patrum sententia designat haereticum. Sanctus vero Hieronymus eius alique opuscula sermone dissertissimo transtulit in Latinum. (CASSIODORUS, c2007, 539-D, p. 1111).

Com essas anotações, Cassiodoro deseja afastar os monges dos erros doutrinários, citando, no final do capítulo, um verso de Virgílio como comentário à leitura de Orígenes: "Aurum in stercore quaero" (CASSIODORUS, c2007, 540-A, p. 1112), "Procuro o ouro no esterco".

Em relação à obra de Cassiano, alerta que deve ser lida com cautela, "unde monemus ut in rebus talibus excedentem sub cautela legere debeatis" (CASSIODORUS, c2007, XXIX, 555-B, p. 1144), "onde avisamos que em tais coisas com cautela devem ler o excesso". A obra de Cassiano, diz Cassiodoro, está presente em Vivarium na edição expurgada, com a ajuda de Deus, de Victor Martyritanus, "Cuius dicta Vistor Martyritano Afer episcopus ita (Domino juvante) purgavit [...] (CASSIODORUS, c2007, XXIX, 555 - B, p. 1144).

Outros alertas podem ser encontrados, com os convites relativos para que os leitores tomem cuidado, como no caso de Ticônio, comentador do Apocalipse:

Ticonium etiam Donatista in eodem volumine quaedam non respuenda [...], quaedam vero venenosi dogmatis sui faeculenta permiscuit. [...] Quod et vobis similiter in suspectis expositoribus facere suademus, ne lectoris animus fortasse turbetur nefandi dogmatis permictione confusus (CASSIODORUS, c2007, IX, 544 - B, p. 1122)

(Também Ticonio Donatista, no mesmo volume de certa forma não deve ser desdenhado, de alguma maneira misturou à verdade as coisas podres de seu dogma venenoso [...]. Aconselhamos a vocês de colocar isso junto aos comentadores suspeitos, para que não perturbem o ânimo confuso do leitor com o silencio do dogma sacrílego). 
Feita tal ressalva, aponta que há partes de Ticônio que podem ser aproveitadas.

Através desses exemplos, podemos observar como Cassiodoro constrói um percurso bibliográfico que inclui, com uma certa liberdade, também autores considerados hereges.

Concluímos aqui nossas observações sobre a obra de Cassiodoro, com a lista dos autores presentes unicamente no I livro do $I D L$. Por razões de espaço, deixaremos tanto os títulos quanto os autores do II livro para outra publicação, bem como a distinção entre os livros sobre os quais há afirmativas de sua presença em Vivarium e os livros recomendados, procurados, conhecidos ou simplesmente citados, mas dos quais não temos notícia sobre sua presença na biblioteca de Vivarium. A razão de colocarmos essa lista reside no fato de querermos oferecer um ensaio da amplitude do trabalho desenvolvido pelo Cassiodoro no âmbito da organização dos saberes da cristandade. Se considerarmos, ao lado dessa lista, que o autor oferece, para praticamente todos eles, um tratamento individualizado sobre os conteúdos e sobre os formatos dos manuscritos, se tornará mais claro o destaque e o significado do gesto bibliográfico do autor, e poderemos, assim, repensar a perspectiva histórica da bibliografia com um fôlego bem maior daquilo que costumamos pensar.

\section{A}

Adamâncio Martyrus

Adriano

Agostinho

Ambrósio

Arusianus Messius

Atanásio Alexandrino

B

Basílio Magno

Bellator

C

Cassiodoro

Célio Aurélio

Cipriano 
Giulia Crippa

Cassiodoro e as Institutiones Divinarum Litterarum como fonte histórica para a discussão sobre práticas bibliográficas e organização do conhecimento

Claudio Ptolomeu

Clemente Alexandrino

Columela

Cúrcio Valeriano

D

Dídimo

Diomedes

Dionísio Exiguo

Dionísio Periegeta

Dioscórides

E

Emiliano

Epifânio Cíprio

Eugippius

Euquério

Eusébio de Cesaréia

Eutíquio

$\mathbf{F}$

Focas

G

Galenus

Gargílio Marcial

Gelásio

Genádio de Marselha

H

Hipócrates

I

Ilário de Poitiers

J

Jerônimo

João Cassiano

João Crisóstomo

José Flávio

Júlio Honório

Junílio

M

Marcelino Comes

Mário Vitorino

Nicetas

$\mathrm{O}$

Orósio

$\mathbf{P}$

Papiriano

Paulinho de Nola

Petrus Abbas Tripolitanus

Possidius

Primásio de Adramento 
Próspero

Próspero de Aquitânia

$\mathbf{S}$

Sócrates

Sozomen

T

Theoctistus

Theodoret

Ticonio Donatista

V

Vélio Longo

Victor Martyriatanus Afer

Virgílio

Virgílio Africano

Vitorino Petaviense

\section{A PREOCUPAÇÃO DE CASSIODORO COM A MEDIAÇÃO DA INFORMAÇÃO: DA PRODUÇÃO DE TEXTOS ÀS DIFERENÇAS NA RECEPÇÃO}

A cultura de Cassiodoro é totalmente embasada na antiga tradição retórica, e não admite intrusão de elementos estranhos no plano da didática, das técnicas e dos instrumentos, ainda que se volte para a constituição de uma nova proposta educacional. É uma cultura da escrita em que a funcionalidade do instrumento gráfico é avaliada somente em sua relação com o legendi iter. Para o autor, a letra corresponde ao elemento base da escrita e da língua: "Littera est pars mínima vocis articulatae" (CASSIODORUS, c2007, IX, 559 - B, p. 1152), isto é, "A letra é a parte menor da articulação da voz", retomando, como ele mesmo alega, a definição clássica do gramático Probo.

A escolha da definição feita por Cassiodoro mostra sua relação com a tradição clássica da escola de Retórica, ainda presente no século VI, revelando os traços de sua educação tradicional quando confrontada com as definições de autores coevos (CURTIUS, 1996). A "vitória" da espiritualidade cristã leva, a partir desse pressuposto ao estado de isolamento e à sensação de "antiguidade" da concepção didática e cultural de Cassiodoro por parte dos maiores estudiosos. 
Pouca importância, nesse sentido, realmente, tem o autor no desenvolvimento filosófico da espiritualidade medieval. Porém, aos poucos, a proposta de biblioteca elaborada por Cassiodoro acaba sendo adotada pela própria ordem beneditina, que substitui gradativamente os preceitos mais simples de escrita e de leitura de sua Regra, a partir do uso que se vê necessitada a fazer de materiais originários de Vivarium (CENCETTI apud CAVALLO, 2003). Após a morte de Cassiodoro, os estudos mostram que a maioria dos livros foi, provavelmente, destinada à biblioteca do Latrão e, em épocas diferentes, foram levados à França e à Inglaterra, para serem copiados. Em particular, durante a época da evangelização da Inglaterra, há referências, em autores notáveis como Beda, às viagens dos abades ingleses para Roma, com a finalidade de se abastecer de livros, muitos dos quais eram obras de gramática. $O$ conhecimento dessa Arte era necessário ao entendimento da Vulgata, em latim, língua que, nessas terras, não pertencia aos novos monges convertidos. Os monges enviados por Gregório Magno, que evangelizam a Inglaterra, levaram consigo livros, e o anglo-saxão Bento Biscop, que na juventude fora para Roma, cria as bibliotecas de Wearmouth e de Jarrow, com base nos manuscritos que levara consigo na volta de sua viagem. Graças à biblioteca de Jarrow, Beda o venerável tornou-se um dos maiores letrados da Alta Idade Média. É no contato com os livros clássicos, profanos e sagrados, que adquiriu um estilo claro e pôde utilizar o latim em suas obras históricas, científicas e escriturísticas. Beda formou Egberto, arcebispo de York em 734, ano de nascimento de Alcuíno, que mais tarde dirigiu a mesma escola, deixando uma espécie de catálogo de todos os livros que possuía. Em 781 Alcuíno encontrou Carlos Magno em Parma, constituindo um sodalício cultural entre os mais importantes da Idade Média, que possibilitou a reorganização e a reunificação da informação escrita naquela que é comumente chamada "Renascença Carolíngia".

Já apontamos como na realidade da organização cultural cristã dos primeiros séculos, o livro encontra seu espaço justamente na 
experiência monástica, através das práticas ascéticas individuais ou comunitárias. O trabalho de transcrição ou a posse de um manuscrito, para o monge era um sustento e, às vezes, uma mercadoria (CUPPOCSAKI, 1997).

Nos Praecepta de Pacômio se fala em códices conservados em um espaço obtido na parede, onde se guardam também diversos objetos de uso doméstico (PETRUCCI apud CAVALLO, 2003). Responsável para os codices resulta ser aquele o "pai da comunidade". $\mathrm{Na}$ Regula Magistri os livros eram confiados a um dos irmãos, que guardava as ferramenta monasterii e várias arcae, cada uma preenchida por objetos de artesanato, domésticos e culturais, reunidos em um único cômodo (PETRUCCI apud CAVALLO, 2003). Entre os ascetas e nas primeiras comunidades monásticas circulavam livros ou textos muito escassos, e a transcrição dos livros era vista como trabalho interno à economia do mosteiro enquanto a distribuição e a retirada dos livros cabiam a um membro da comunidade.

Vivarium revela uma diversidade organizacional inconciliável com aquela das primeiras comunidades: havia, de fato, um scriptorium e um adequado sistema de conservação dos livros. Os códices eram preparados em quaterniones ou seniones, com a anexação dos fascículos (CAVALLO, 2003 apud ARDUINI, 2008), a tipologia de cada manuscrito variando em função do texto e do uso para o qual os próprios códices se destinavam. Utilizavam-se escritas de módulo diferenciado para códices de qualidade textual e técnica particular. Em alguns casos, como pode ser observado pelas anotações do próprio Cassiodoro no $I D L$, era disponível uma série de instrumentos auxiliares de leitura e consulta, e era possível encontrar tanto as obras de um autor único quanto os escritos de vários autores: estes eram reunidos em um volume único ou em poucos tomos, para serem consultados com facilidade maior.

Também a encadernação era considerada como muito importante. O cuidado "crítico" dedicado ao texto era praticado através 
Cassiodoro e as Institutiones Divinarum Litterarum como fonte histórica para a discussão sobre práticas bibliográficas e organização do conhecimento

da colação com os antigos e executado com a ajuda da voz de um leitor. A devolução do texto era regulamentada por normas exatas. A incompetência dos scriptores deixava, às vezes, erros no texto que comprometiam a compreensão e, portanto, era necessária uma Decora Correctio, que também dizia respeito à estética do livro. As correções eram realizadas de maneira que a escrita do revisor não se diferenciasse daquela profissional (CAVALLO, apud CAVALLO; FEDELI; GIARDINA, 1998). A biblioteca de Vivarium era constituída por Armaria numerados, onde os códices, de conteúdo sacro, profano, latino ou grego, eram guardados, e os sistemas e técnicas de produção do manuscrito reproduziam aqueles praticados nas escolas cristãs tardoantigas (VAN DE VYVER, 1931).

Cassiodoro, estimula a transmissão de uma cultura funcional e de um patrimônio destinado aos iletrados, através da pregação. Nesse sentido, é um dos teóricos profundamente convencidos da necessidade de uma lógica cultural multipla, portanto de uma produção cultural diferenciada em vários níveis, mediados por um grupo "técnico" de comunicação: os pregadores.

Essa preocupação encontra-se já nas Variae, um conjunto dos escritos mais juvenis de Cassiodoro, reunidos em doze volumes em que são reunidos assuntos de natureza diversa. Como exemplo, leia-se a seguinte citação, relativa aos estilos a serem utilizados:

Librorum vero titulum, operis indicem, causarum praeconem, totus orationis brevissimam vocem, variarum nomine praenotavi, quia necesse nobis fuit stilum, non unum sumere, qui personas varias suscepimus ammonere, aliter enim multa lectione satiatis, aliter mediocri gustatione suspensis, aliter a litterarum sapore ieiunis persuasionis causa loquandum est, ut interdum genus sit peritiae vitare quod doctis placeat. Proinde maiorum pulchra definitio est sic apte dicere, ut audientibus possis concepta vota suadere, neque enim tria genera dicendi in cassum prudens definivit antiquitas: humile, quod communione ipsa serpere videatur; médium, quod $\mathrm{Nec}$ magnitude tumescit $\mathrm{Nec}$ parvitate tenuatur, sed inter utrum que positum própria venustate 
ditatum suis finibus continetur; tertium genus, quod ad summum apicem disputationis exquisitis sensibus elevatur; videlicet, ut varietas personarum congruum sosrtiretur eloquium et, licet $a b$ uno pectore proflueret, diversis tamen alveis emanaret, quando nullus eloquentis obtinet nomen, nisi qui trina ista virtute succintus causis emergentibus viriliter est paratus ${ }^{1}$ () (CASSIODORO, 1894, Variae, Praefatio, 15-17, p. 5).

$\mathrm{Na}$ manifestação dessas preocupações encontra-se o paradoxo de uma reaproximação dos problemas contemporâneos de disponibilização da informação "desmaterializada" pelas tecnologias digitais, lá onde no século VI a "desmaterialização" era necessária pela falta de disponibilidade de materiais. Observa-se, assim, a busca de soluções em "plataformas" diversificadas (a voz, a imagem, o texto escrito) e a procura de linguagens capazes de alcançar os mais variados públicos. Que as soluções propostas tenham dado certo, pode ser verificado na amplidão de espaço e tempo da eficácia dos processos de evangelização. O que ressaltamos, aqui, é que a figura de Cassiodoro, seu pensamento e sua obra, com certeza se colocam como uma das bases de sustentação de todo esse processo, que só encontrará suas efetiva virada com a invenção do livro impresso e, consequentemente, com uma nova abordagem sobre a textualidade escrita.

\footnotetext{
${ }^{1}$ (Como título desses livros, para designar o caráter e os assuntos e sintetizar em uma palavra o conteúdo, escolhi o de Variae, pois foi forçado a não usar um único estilo, precisando me endereçar a pessoas diversas. Diversamente, de fato, deve-se falar para pessoas preenchidas por muitas leituras, ou para pessoas de cultura medíocre, ou para quem è totalmente alheio às letras, querendo persuade-lo, tanto que, às vezes, è uma forma de perícia literária evitar aquilo que os doutos gostam. Não à toa, de fato, a sábia Antiguidade separou três gêneros de eloquência: a humilde, que para seu próprio caráter de linguagem comum parece se arrastar no chão, o médio, que não se eleva à grandiosidade nem decai no desleixo, mas se mantém dentro dos próprios limites, entre um e outro extremos, dotado, porém, de uma sua graça, e um terceiro gênero, que, pela altura dos conceitos e das formas se eleva aos cumes mais excelentes do dissertar; certamente, para que toda variedade de pessoas pudesse dispor de uma linguagem própria, e essa, mesmo surgindo de um único peito, corresse, todavia, por caminhos diversos, pois não pode ser chamado de eloqüente aquele que não esteja armado dessa tríplice virtude, pronto para enfrentar vigorosamente as situações que se apresentam).
} 


\section{CONCLUSÕES}

Há, evidentemente, uma distância enorme entre o catálogo bibliográfico de Cassiodoro e as práticas bibliográficas contemporâneas, ligadas a repertórios praticamente infindáveis constituídos pelas redes tecnológicas. Todavia, é necessário percorrer os elementos que afloram através das camadas sobrepostas de tecnologias para guarda, reprodução e circulação da informação, para nos apercebermos da permanência do gesto que caracteriza a arte da bibliografia, no seu sentido de techné, construção "pragmática" de caminhos, percursos de conhecimento através dos registros selecionados. Colocando às luzes os princípios de sua proposta bibliográfica, Cassiodoro constrói esse precoce catálogo raisonneé que oferece toda a dimensão do território, da geografia de saberes cristãos da época a serem percorridos por essa trajetória especifica do conhecimento. É claro que a fonte estudada permite maiores explorações, inclusive em relação às referências a outros autores (TRONCARELLI, 1998). Nos limitamos, aqui, à elaboração de uma lista que o próprio Cassiodoro explícita, através da leitura do próprio texto.

O que aflora no tempo longo de uma história cultural que se dispõe a investigar as permanências e as mudanças do conceito de biblioteca nas várias épocas, é a reflexão sobre práticas e criação de modelos de informação do passado, com base nos quais se torna possível medir, com certeza, os processos de inovação tecnológicos. Destacam-se, porém, na reconstituição histórica, as questões conceituais do campo da Informação, como algo que, muitas vezes, independe das temporalidades, mas se conectam, de maneira mais adequada, aos problemas que a interferência das tecnologias resolve de maneira mais eficiente, mas basicamente preservando a natureza do "gesto bibliográfico" na contemporaneidade.

O IDL é, nesse sentido, muito mais do que um catálogo de uma biblioteca, um registro manuscrito já sem significado, a não ser para os 
historiadores da Alta Idade Media. É um texto que revela as múltiplas facetas de um dispositivo da cultura manuscrita, preocupada com sua imanência física na biblioteca e com a dimensão filosófica do conhecimento, explicitando os aspectos descritivos e semânticos dos documentos e dos saberes, contribuindo, nos termos de uma história que se torna antropologia na medida em que estuda o gesto bibliográfico às dimensões conceitual das disciplinas bibliográficas.

A estrutura da bibliografia de Cassiodoro adquire, na lógica das preocupações que ele mesmo expressa em todo seu percurso intelectual, uma função concreta nas reflexões sobre as atividades bibliográficas mais contemporâneas, pois o gesto de devolver os traçados do conhecimento, seus registros materiais com suas marcas e a representação dos conteúdos documentários são, hoje em dia, algumas das preocupações centrais das Ciência da Informação.

Da mesma maneira, ainda que de forma reduzida por questões de espaço, tentamos jogar uma luz sobre a preocupação desse mesmo autor com o que costumamos chamar, hoje, mediação. Com efeito, por um tempo demasiadamente longo considerou-se a Idade Média uma época em que a informação não circulava. Certamente, não circulava em seu suporte escrito, pela escassez e pelo custo do registro material. Porém, não somente era sentida profundamente a preocupação com a disseminação dos conteúdos, bem como havia uma consciência muito apurada das diferenças culturais existentes para sua apropriação. Nesse sentido, será necessário discutir, em outro momento, como o fenômeno foi se transformando quando a tecnologia da impressão modificou a relação com a mediação da informação.

\section{REFERÊNCIAS}

AGAMBEN, Giorgio. 0 amigo \& o que é um dispositivo? Chapecó: Argos, 2014. 
ARDUINI, Franca: La forma del libro: dal rotolo al codice (secoli III a.C - XIX d.C.). Firenze: Mandragora, 2008.

BOWMAN, Alan K.; WOOLF, Greg. Cultura escrita e poder no mundo antigo. São Paulo: Ática, 1998.

CARRUTHERS, Mary: Machina memorialis: méditation, rhétorique et fabrication des images au Moyen Âge. Paris: Gallimard, 2002.

CASSIODORO, Flavio Magno Aurelio: (s.d.) Opera Omnia in duos tomos distributa. In: MIGNE, J. P. Patrologia latina tomus 70. Turnhout: Brepols, [18 --?] .

CASSIODORO, Flavio Magno Aurelio. Variae. In: MOMMSEN, Theodor (Ed.). Momumenta germaniae historicae. Berlim: Weidmann, 1894. Disponível em:

<http://www.dmgh.de/de/fs1/object/display/bsb00000824_00189.html?so rtIndex=010\%3A010\%3A0012\%3A010\%3A00\%3A00>. Acesso em: 9 mar. 2015.

CASSIODORUS, Flavius Magnus Aurelius. Institutiones divinarum et saecularium litterarum. Roma: Ėulogos SpA, c2007.

CAVALLO, Guglielmo. (Org.). Libri e lettori nel medioevo: guida storica e critica. Bari: Laterza, 2003.

CAVALLO, Guglelmo; FEDELI, Paolo; GIARDINA, Andrea. (Org.): Lo spazio letterario di Roma Antica: la circolazione del testo. Roma: Salerno, 1998.

COLISH, Marcia: La cultura del Medioevo. Bologna: II Mulino, 2001.

COURCELLE, Pierre: Les lettres grecques en occident: de Macrobe a Cassiodore. Paris: E. de Boccard, 1948.

CUPPO-CSAKI, Luciana: Beautus Cassiodorus. Vivarium Scyllacense, Squillace Ano 8, n. 2, p. 13-34, 1997. Disponível em:

<http://www.cassiodoro.it/vivarium-scyllacense/Kuppo-CsakiVIII-2-

97.htm>. Acesso em: 9 mar. 2015

CURTIUS, Ernst R. Literatura europeia e idade média latina. São Paulo: Hucitec, 1996.

HALPORN, James W. Methods of reference in Cassiodorus. Journal of Library History, Tallahassee, v. 16, n. 1, p. 71-91, 1981.

JONES, Leslie W. The influence of Cassiodorus on Medieval culture. Speculum, 22, pp. 433-442, 1947. 
Cassiodoro e as Institutiones Divinarum Litterarum como fonte histórica para a discussão sobre práticas bibliográficas e organização do conhecimento

O’DONNELL, James J.: Cassiodorus. Berkeley: University of California Press, 1979.

RICHÉ, Pierre. Ecoles et enseignement dans le haut moyen âge: fin du Ve siècle-milieu du Xle siècle. Paris: Picard, 1999.

SÃO VITOR, Hugo de. Didascálicon: da arte de ler. Petrópolis: Vozes, 2001.

TRONCARELLI, Fabio. Vivarium: i libri, il destino. Brepols: Turnhout, 1998.

VAN DER VYVER, Andrè. Cassiodore et son oevre. Speculum, 6, pp. 244-292, 1931.

Title

Cassiodorus and the Institutiones Divinarum Litterarum as an historical font for discussion on bibliographical practices and knowledge organization.

\section{Abstract}

Introduction: The Science of the Information discusses the access and use of Information. Among these discussions, we consider that Bibliography represents one of the foundations, being considered a meta- disciplin, for the treatment of documents. When it is observed from a perspective of "bibliographical gesture", we may perceive that its history is well previous to the invention of the impression of books, being able to be individualized in its main elements in one work from the 6th century, the De Institutione Divinaruam Litterarum, written by Cassiodorus (c. 490-c. 584).

Objectives: 1) Historically reconstitute the recurrence of informational problems, facing them from an intellectual point of view, through an historical source, the De Institutione Divinarum Litterarum, of Bibliographical nature.

2) Study the "bibliographical gesture" carried through by Cassiodoro when of the collapse of the structures of the Delayed Antiquity.

3) Observe the trajectory of a reorganization of knowledge its heathen and Christian registers in search of new paths for knowledge considered not only legitimate, as well as structural for society, offering a small sample of this source, one of the first dedicated to the medieval knowledge, articulated as manual of instruction, map of authors and their use and place in the hierarchy of knowledge.

4) Discuss some aspects of Cassiodorus' work, device of selection, organization and informational mediation.

Methodology: Revision of literature and reading of sources.

Results: First attempt of systematization of Fathers' literature (to which the same Cassiodorus gave a notable contribution, composing a large Commentary to the Psalms), the nine chapters of the De Institutione Divinarum Litterarum is a book made of books, through the canonic authors of religious literature, a list 
of works considered essential in the scaling of divine knowledge, having its presence justified by the creation of a program of Christian education and its materiality largely described. The text is completed by commentaries dedicated to writing and translation, delineated in few and clear lines.

Conclusions: The De Institutione Divinarum Litterarum it is a text that discloses the multiple facets of a device of manuscript culture, worried about its physical presence in the library and about the philosophical dimension of the knowledge, explaining the descriptive and semantic aspects of the documents and of knowledge, contributing, in terms of a history that becomes anthropological, in the measure in which it studies the bibliographical gesture, to the conceptual dimensions of bibliographical contemporaries disciplines.

Keywords: Bibliography - History and Theory. Bibliographers - History. De Institutione Divinarum Litterarum - 6th Century. Cassiodorus. Bibliographical act.

\section{Titulo}

Cassiodoro y las Institutiones Divinarum Litterarum como fuente histórica para la duscussion sobre las practicas bibliograficas e la organización del conocimiento.

\section{Resumen}

Introduccíon: La ciencia de la información discute el acceso y al uso de la información. En el alcance de tales peleas, consideramos que la bibliografía representa una de las fundaciones, en cuánto meta-disciplina, para el tratamiento de documentos. Si observado por la perspectiva del "gesto bibliográfico", se percibe que su historia es bien anterior a la invención de la impresión de libros, pudiendo ser individualizada en sus elementos principales en uno tratado del siglo $\mathrm{VI}$, el De Institutione Divinaruam Litterarum de Cassiodoro (C. 490 c. 584).

Objetivos: 1) Reconstituir históricamente la vuelta de los problemas de la información enfrentando-los de un punto de vista intelectual, con una fuente histórica, el De Institutione Divinarum Litterarum, de naturaleza bibliográfica.

2) Estudiar el "gesto bibliográfico" realizado por Cassiodoro cuando del derrumbamiento de las estructuras de la Antigüedad Tarda.

3) Observar la trayectoria de una reorganización de los saber y de los registros paganos y el cristianos, en la búsqueda de un percurso del conocimiento considerado no sólo legítimo, así como estructural para la sociedad, ofreciendo una muestra pequeña de esta fuente, una de las primeras dedicada al conocimiento medieval, articulada como manual de instrucción, mapa de autores y de su uso y lugar en la jerarquía de los saberes.

4) Discutir algunos aspectos de la obra de Cassiodoro, como dispositivo de la selección, de la organización y de la mediación informacional.

Metodología: Revisión de la literatura y lectura de las fuentes.

Resultados: Primera tentativa de la sistematización de la literatura patrística (a que Cassiodoro dio una notable contribución, con la composición de un imponente comentario a los Salmos), los nueve capítulos del De Institutione 


\section{Giulia Crippa}

Cassiodoro e as Institutiones Divinarum Litterarum como fonte histórica para a discussão sobre práticas bibliográficas e organização do conhecimento

Divinarum Litterarum son un libro hecho por libros, con autores del canon de la literatura religiosa, una lista de obras consideradas esenciales en el escalamiento para el conocimiento divino, su presencia justificada en la creación de un programa de educación cristiana y de su materialidad descrita. El texto es completado por comentarios dedicados a la escritura y a la traducción delineadas con pocos y claros tratos.

Conclusiones: El De Institutione Divinarum Litterarum es un texto que divulga a los facetas múltiples de un dispositivo de la cultura manuscrita, preocupado con su presencia física en la biblioteca y con la dimensión filosófica del conocimiento, explicitando los aspectos descriptivos y semánticos de los documentos y de los saberes, contribuyendo, en los termos de una historia que si se convierte en antropología en la medida en que estudia el gesto bibliográfico, para las dimensiones conceptuales de las disciplinas bibliográficas contemporáneas.

Palabras-clave: Bibliografía - Historia y Teoría. Bibliógrafos - Historia. De Institutione Divinarum Litterarum - siglo VI. Cassiodoro. bibliografica. Gesto bibliografico.

Recebido em: Abril de 2015

Aceito em: Julho de 2015 